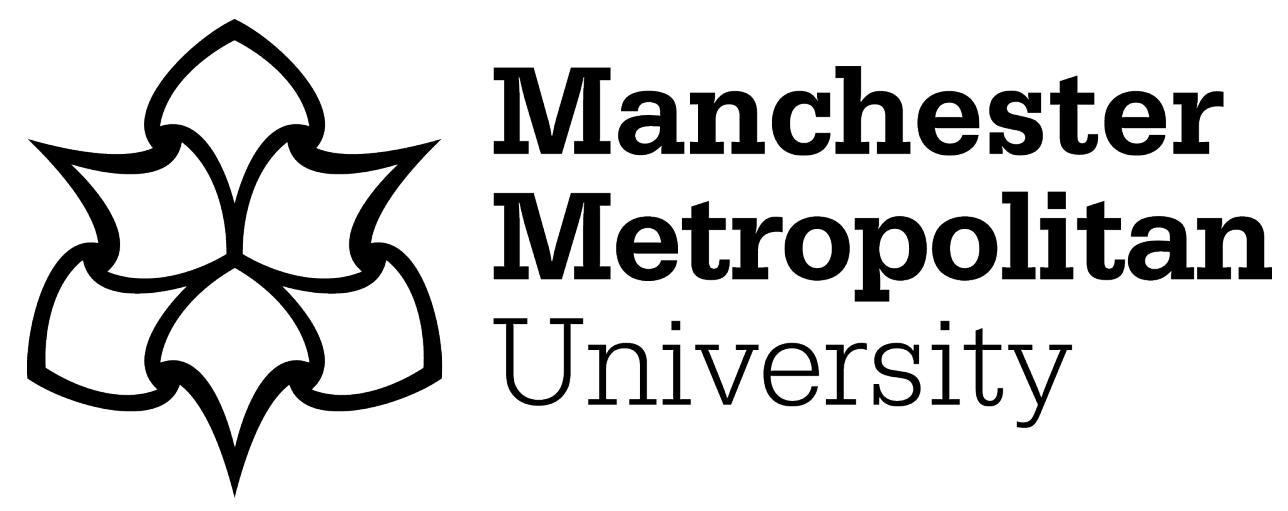

Stobart, Jon ORCID logoORCID: https://orcid.org/0000-0002-9771-4741 (2021) Genteel or respectable? The material culture of rural clergy in late Georgian England. In: The Social Life of the Early Modern Protestant Clergy. University of Wales Press. ISBN 9781786837141

Downloaded from: https://e-space.mmu.ac.uk/627101/

Version: Accepted Version

Publisher: University of Wales Press

Please cite the published version 


\section{Genteel or respectable? The material culture of rural clergy in late Georgian England}

In August 1790, the Northampton auctioneer Mr Rouse published 'A catalogue of the entire elegant, genteel and useful household furniture, plate, linen, china, books, and other valuable effect of the Rev Zacharias Rose, A.M., late Rector of Broughton and Draughton'. ${ }^{1}$ As this announcement makes very clear, the houses of the rural clergy could contain a wide variety of high quality furnishings. It underlines that men such as the Rev Rose often formed part of the elite in English villages, elevated in economic and material as well as social terms. They occupied what was frequently the largest house in the village and sometimes enjoyed close links with the local gentry. These connections reflected the rise in social standing of certain sections of the clergy through the eighteenth century and were reinforced by the common practice of using lucrative livings as a means of setting up the younger sons or cadet branches of landed gentry families. ${ }^{2}$ As William Bray noted of the Drake family of Amersham: 'one of the gentleman's sons is presented by him to the living, which, from its value, and the goodness and situation of the parsonage house, is no bad establishment for a younger son' ${ }^{3}$ Such sinecures, and the pluralism which characterised the eighteenth and early nineteenth century, meant that parsons were often well-connected and well-housed. Bax has described in detail the ways in which prosperous clergymen were willing and able to rebuild their houses, a practice which Parson Woodforde noted in one of his neighbours, the Rev Mr Attle. After visiting his neighbour in April 1779, Woodforde recorded that he had 'a noble house and his fields about him look exceeding neat and well. He built the House himself and it cost him 1000 Pound'. ${ }^{4}$ He also noted that he had taken coffee and tea with Attle, but he made no comment on the interior of the house or its decoration and furnishings.

Like Woodforde, historians have shown relatively little interest in the material lives of the clergy, beyond broad attacks on eighteenth-century venality, from which they are slowly

\footnotetext{
${ }^{1}$ Northamptonshire Central Library (hereafter NCL), Sale Catalogue for Broughton rectory, 1790, M0005646NL/10.

${ }^{2}$ B.A. Bax, The English Parsonage (London, 1964), pp.102-04.

${ }^{3}$ W. Bray, Sketch of a Tour into Derbyshire and Yorkshire (London, second edition, 1783),

${ }^{4}$ J. Woodforde, The Diary of a Country Parson, 1758-1802 (Norwich, 1999), p.107.
} 
being rescued. ${ }^{5}$ Where this has been attempted, attention has been focused firmly on the architecture of the parsonage or on the episcopate rather than ordinary clergymen. ${ }^{6}$ In Lorna Weatherill's analysis of changing domestic material culture in late seventeenth and early eighteenth century England, the clergy are placed with 'trades of high status'. ${ }^{7}$ They are thus one notch down from the gentry, but they shared similar patterns of ownership in the key goods on which her analysis was focused. Weatherill's primary purpose was to trace change in English homes, rather than determine what it might tell us about social standing. However, the shifting patterns of ownership that she identified were part of longer term changes that were apparent much earlier. Indeed, the widening attraction and accessibility of luxury consumption was already a social phenomenon in the sixteenth century when William Harrison noted that it had spread 'even unto the inferior artificers and many farmers' who had 'learned also to garnish their cupboards with plate, their joint beds with tapestry and silk hangings, and their tables with carpets and fine napery'. ${ }^{8}$ For Harrison and for many other commentators, this was an alarming trend; one that threatened to break down a long established system of material markers that distinguished different social groups. Rising incomes amongst the middling sort created increasingly blurred distinctions of wealth and opened up new possibilities for consumption, fuelled in part by the influx of new goods and commodities. ${ }^{9}$ Elsewhere in Europe, this led to the imposition and reiteration of sumptuary laws; in England, such legislation was much less common and largely unenforced, even when

\footnotetext{
${ }^{5}$ See, for example, W. Sheils and D. Wood (eds), The Church and Wealth (Cambridge, 1987); W. Gibson, The Achievement of the Anglican Church, 1689-1800 (Lewiston, 1995); Goldie, M., 'Voluntary Anglicans', The
} Historical Journal, vol 46 (2003).

${ }^{6}$ Bax, English Parsonage; T. Brittain-Catlin, The English Parsonage in the Early Nineteenth Century (Reading, 2008); M. Ashby, 'Episcopal palaces in Georgian England: form, function and meaning' University of Cambridge $\mathrm{PhD}$ thesis, 2015.

${ }^{7}$ L. Weatherill, Consumer Behaviour and Material Culture in Britain, 1660-1760 (London, second edition, 1996), pp.165-89.

${ }^{8}$ W. Harrison, The Description of England (London, 1587), p.197.

${ }^{9}$ The classic studies include: N. McKendrick, J. Brewer and J. Plumb, The Birth of a Consumer Society (London, 1982); P. Earle, The Making of the English Middle Class: Business, Society and Family Life in London 1660-1730 (Los Angeles, 1989); P. Langford, A Polite and Commercial People: England 1727-1783 (Oxford, 1989); P.J. Corfield, Power and the Professions in Britain, 1700-1850 (London: Routledge, 1995); M. Berg, Luxury and Pleasure in Eighteenth-Century Britain (Oxford, 2005); 
enacted. ${ }^{10}$ There was a social and material fluidity that could be exploited by individuals and social groups to realign themselves within the social hierarchy. This was most apparent in terms of personal appearance, leading to confusion and sometimes despair about who was a gentleman and how they might be identified. As Guy Miege noted as early as 1699 that anyone with 'either a liberal or genteel education, that looks gentleman-like (whether he be so or not) and has the wherewithal to live freely and handsomely, is by the courtesy of England usually called a gentleman'. ${ }^{11}$ However, this blurring of boundaries was also apparent in the domestic setting - as Harrison makes clear. People could render themselves genteel through their drawing rooms as well as their dress. Alongside country seats and villas for the gentry, architectural treatises offered models for elegant parsonages and farmhouses for the socially ambitious who could also draw on furniture pattern books to commission tasteful pieces from local craftsmen. ${ }^{12}$

In this paper, I draw on a sample of twenty-one sale catalogues for rural clergymen in Northamptonshire, in the English Midlands, between 1761 and 1842 to discover the nature and quality of their domestic material culture. The sample is modest and it is clear that sales did not always involve all the goods in the house, but auction catalogues provide a unique insight into domestic material culture in late eighteenth and early nineteenth century, not least because they provide much richer descriptions of household goods than we see in inventories, in part because of the imperative to sell. My concern is twofold. First, I want to examine their ownership of a range of luxury and semi-luxury goods, broadly defined, as it is revealed through the goods being sold, generally post-mortem. In particular, I am concerned with the extent to which their belongings compare with those of the gentry of the county and allowed these clergymen to align themselves with genteel and tasteful domestic life. Building on this, I explore the ways in which their possessions were described in the sale catalogues, using this as a mechanism for assessing the quality of goods but also as an indication of the broader

\footnotetext{
${ }^{10}$ See A. Hunt, Governance of the Consuming Passions: History of Sumptuary Law (Basingstoke, 1996); D. Roche, The Culture of Clothing: Dress and Fashion in the Ancien Regime (Cambridge, 1996); A. Pajur, 'The fabric of a corporate society: sumptuary laws, social order and propriety in early modern Tallin', in J. Ilmakunnas and J. Stobart (eds) A Taste for Luxury in Early Modern Europe (London, 2017), pp.21-38.

${ }^{11}$ Quoted in Earle, Making of the English Middle Class, p.6. Many clergymen qualified on all of these fronts.

${ }^{12}$ Examples of architectural treatises incorporating designs for parsonages include: W. Halfpenny, Useful Architecture in Twenty-one new designs for Country Parsonages, Farm Houses and Inns (London, 1752); J. Crunden, Convenient and Ornamental Architecture ... (London: J. Taylor, 1788).
} 
systems of taste and cultural norms with which the clergy might be aligned. Ultimately, my aim is to determine whether these material possessions positioned their clergy owners as genteel or merely respectable, or whether they suggest a more specific social niche that was particular to the prosperous clergy.

\section{Household goods: markers of status.}

Rather than examine the full range of goods to be found in clergymen's houses, I want to focus here on those items that marked their status. This is not because the pots and pans in the kitchen or the pillows and blankets in the bedrooms were unimportant; far from it, they tell us much about daily life in even the grandest of houses. ${ }^{13}$ However, other types of goods were more obviously important and conspicuous in carrying messages about the wealth and status of the owner, and in marking them out from other sections of society. For Thorstein Veblen, consumption by the leisure classes 'undergoes a specialisation as regards the quality of the goods consumed. Since the consumption of these more excellent goods is an evidence of wealth, it becomes honorific; and conversely the failure to consume in due quantity and quality becomes a mark of inferiority and demerit'. ${ }^{14}$ Defining the precise character of these 'excellent goods' is problematic. ${ }^{15}$ Thinking of them purely in terms of luxury is unhelpful; rather, they were positional goods in that their value was used to mark out status, but their excellence was not merely a reflection of cost, it also encompassed notions of discernment, as Veblen put it, to discriminate with some nicety between the noble and the ignoble in consumable goods'. ${ }^{16}$ Looking back from the early twentieth century, Sombart drew on contemporary sources to argue that domestic luxury formed the area of enormous and growing expenditure: crystal lamps, busts and medallions, carved marble chimneys, Asian

\footnotetext{
${ }^{13}$ J. Stobart and M. Rothery, Consumption and the Country House (Oxford, 2016), 83-108; J. Whittle and E. Griffiths, Consumption and Gender in the Early Seventeenth-Century Household (Oxford, 2013), pp.86-116.

${ }^{14}$ T. Veblen, The Theory of the Leisure Class: an Economic Study of Institutions (1899; London: Penguin Classics Edition, 1994), p.74. We need to be careful about taking Veblen's writing entirely at face value, but he rightly points to the importance of goods as social markers.

${ }^{15}$ For discussion of the concept of luxury, see: Berg, Luxury and Pleasure, pp.21-45; C. Berry, The Idea of Luxury. A Conceptual and Historical Investigation (Cambridge, 1994), pp.138-9; L. Peck, Consuming Splendor: Society and Culture in Seventeenth-Century England (Cambridge, 2005), pp.1-24.

${ }^{16}$ Veblen, Theory of the Leisure Classes, p.74.
} 
textiles, gilded furniture and magnificent clocks. ${ }^{17}$ The impression is confirmed by Amanda Vickery's analysis of the Georgian interior, although she notes that new forms of luxury goods were balanced by others that were more established, much of the spending of mideighteenth-century gentlemen still being centred on coaches, horses and wine cellars. ${ }^{18} \mathrm{I}$ have argued elsewhere that the houses of the lesser gentry were characterised by a widening array of such goods and that many of them were sold off in house sales when they died. ${ }^{19} \mathrm{My}$ question here is whether the clergy were part of this same material culture.

Table 1. Presence of categories of goods in catalogues for gentry and clergy house sales in Northamptonshire, 1761-1842

\begin{tabular}{lcccc}
\hline & \multicolumn{2}{c}{ Gentry $(\mathrm{n}=24)$} & \multicolumn{2}{c}{ Clergy $(\mathrm{n}=21)$} \\
& Number & Percentage & Number & Percentage \\
\hline Furniture, mirrors \& curtains & 24 & 100 & 20 & 95 \\
Glass \& chinaware & 20 & 83 & 20 & 95 \\
Table and household linen & 11 & 46 & 8 & 38 \\
Prints \& paintings & 17 & 71 & 13 & 62 \\
Books & 8 & 33 & 13 & 62 \\
Scientific instruments & 11 & 46 & 6 & 29 \\
Wine & 9 & 38 & 4 & 19 \\
Silverware & 10 & 42 & 3 & 14 \\
Carriages & 7 & 35 & 8 & 38 \\
Collections \& antiques & 8 & 33 & 0 & 0 \\
\hline
\end{tabular}

Source: Volumes of auction catalogues, Northamptonshire Central library, M0005644-7NL

Enumerating the types of goods listed in the sale catalogues reveals that these two groups had much in common (Table 1). Unsurprisingly, furniture, mirrors and curtains, and glass and chinaware were found in the vast majority of sales, the exceptions coming when the auction

\footnotetext{
${ }^{17}$ W. Sombart, Luxury and Capitalism (Munich, 1913; English edition, Chicago, 1967), p.105.

18 A. Vickery, Behind Closed Doors. At Home in Georgian England (New Haven, 2009), pp.124-5. See also H. Grieg, 'Leading the fashion: the material culture of London's beau monde', in J. Styles and A. Vickery (eds), Gender, Taste and Material Culture in Britain and North America 1700-1830 (New Haven, 2006), pp.293-313

19 J. Stobart, 'Luxury and country house sales in England, c.1760-1830', in A. Fennetaux, A. Junqua and S. Vasset (eds), The Afterlife of Used Things. Recycling in the Long Eighteenth Century (London, 2015), pp.25-36.
} 
focused on libraries (as at the rectory in Stilton in 1807) or where auctions appear to have been selling off specific items, sometimes following earlier sales at the same house (Geddington in 1828 and 1829). Prints, paintings, clocks and linens were found in 40-50 per cent of both gentry and clergy sales, the modest showing of the last of these reflecting a general decline in the sale at house auctions at least of second-hand textiles, despite the continued importance of linen to displays of polite dining and cleanliness. ${ }^{20}$ Much the same was true of musical instruments, ornamental items, musical instruments and scientific equipment, where ownership amongst the clergy was only slightly lower than amongst the gentry. More surprising, perhaps, is that carriages appeared in the sale catalogues of clergymen as often as they did those of gentlemen, an indication of the social standing of the former, but also their wealth: a carriage also meant keeping one or more horses, although it is more likely that the clergymen were using the same horses for riding. ${ }^{21}$

The key areas where the clergy and gentry diverged in their material culture - at least in terms of the type of things found in their homes - came in terms of books, wine, silverware and collections, including antiques. These can all be viewed as positional goods, but their different importance in gentry and clergy houses points to a slight divergence in the construction and articulation of their social standing. Sales from the houses of clergymen were twice as likely to include books, although - as with country house libraries - the size and composition of these clergy libraries varied considerably. ${ }^{22}$ The books of the Rev Haggit in Rushton, were auctioned off in 1798 in just 29 lots, but in many other cases there were dozens or even hundreds of lots, many containing a number of books or books that came in several volumes; the largest was the 511 lots required to clear the library of the Rev Speidell at Crick in $1836 .{ }^{23}$ Naturally the core of these libraries comprised books on religion - bibles, sermons, lexicons, and the like - but many were far more wide ranging. The Rev Speidell owned books on religion, but also volumes of poems, plays and music, histories, guides,

\footnotetext{
${ }^{20}$ J. Stobart, 'Domestic textiles and country house sales in Georgian England', Business History, vol 61:1 (2019), pp.17-37; W. Smith, Consumption and the Making of Respectability, 1600-1800 (London: Routledge, 2002).

${ }^{21}$ P. Edwards, Horse and Man in Early Modern England (London: Bloomsbury, 2007)

${ }^{22}$ On the libraries of gentlemen and aristocrats, see M. Purcell, The Country House Library (London: Yale University Press, 2017).

${ }^{23}$ NCL, Sale Catalogue for Rushton rectory, 1798, M0005646NL/17; Sale Catalogue for Crick rectory, 1836, M0005644NL/19.
} 
dictionaries, medical books and novels; the Rev Laurence in East Farndon (where the sale too place in 1838) had books on history, government and gardening, plus several journals. ${ }^{24}$ In this, clergy libraries were similar in composition and sometimes size to many country house libraries and no doubt carried similar messages of learning and status - something which is perhaps unsurprising given the shared university education of sections of the gentry and clergy. ${ }^{25}$ It is also clear that at least some clergymen were discerning bibliophiles, their libraries containing numerous books from the seventeenth and even the sixteenth century, sometimes held in high quality bindings. At Crick, there were seventeenth-century histories and bibles; a copy of Lodge's Portraits of Illustrious Personages of Great Britain (1821), described as 'a choice copy, fine impressions, calf elegant, gilt leaves', and Clarendon's History of the Rebellion (1816), which is listed as 'uncut' - an indication that the clergy sometimes owned books for display as well as reading. ${ }^{26}$ At Ecton in 1838, the Rev Whalley had a Latin Testament from 1582, Luther's Commentary from 1588 and a 1601 edition of Ovid in Latin - just a handful of a much bigger collection of old books. ${ }^{27}$ Like those in the country houses of gentlemen, these clergy libraries were to be read and studied, but also displayed and admired. That they often took as many days to auction off as the rest of the household goods speaks of the interest they held for buyers, no doubt including other clergy and gentlemen.

Beyond the library, what these clergy house sales lacked in comparison with their gentry counterparts were some of the established markers of status, what de Vries describes as old luxury: goods distinguished by their exclusiveness, cost and complexity. ${ }^{28}$ This might be seen in terms of individual items: elaborate cabinets such as that sold from Rolleston Hall in 1801 which was described in the catalogue as a 'mahogany case of four large, and two small

\footnotetext{
${ }^{24}$ NCL, Sale Catalogue for Crick rectory, 1836, M0005644NL/19; Sale Catalogue for East Farndon rectory, 1838, M0005644NL/22

${ }^{25}$ Purcell, Country House Library, pp.112-31.

${ }^{26}$ NCL, Sale Catalogue for Crick rectory, 1836, M0005644NL/19, 39. On the bibliomania that encouraged such collecting, see Purcell, Country House Library, 160-79; one its spread beyond the elite, see I. Mitchell, Tradition and Innovation in English Retailing, 1700 to 1850 (Farnham: Ashgate, 2014), pp.119-24

${ }^{27}$ NCL, Sale Catalogue for Ecton rectory, 1838, M0005644NL/24.

${ }^{28}$ J. de Vries, The Industrious Revolution: Consumer Behavior and the Household Economy, 1650 to the Present (Cambridge: Cambridge University Press, 2008), pp.44-5.
} 
compress drawers; the upper part, with folding doors, encloses a valuable ebony cabinet, the fronts of the drawers of which are MOST DELICATELY PENCILLED with the history of the journeying the Israelites in the Wilderness, and a great number of exquisite miniature figures' ${ }^{29}$ Old luxury might also be seen in an impressive array of silverware or in collections of coins, medallions or rare china. These are seen in the houses of the gentry, for example, the 'plaster bustos' and 'Five Collections of Medals in plaster, fram'd and glaz'd' sold at Cottingham in 1762 or the coin collection belonging to J.P. Clarke, esquire (1830), which ran to 16 lots including: English and foreign silver coins, provincial coins, and Greek and Roman coins (the latter carefully categorised by Caesar), and silver medals. ${ }^{30}$ Such items were not wholly absent from the homes of clergymen - there were marble slab tables at Broughton and Crick, whilst the Rev Goode at Weldon (1761) had 'Seven pieces of curious Tapestry, containing the History of Moses'. ${ }^{31}$ However, when they do appear, they are often one-off items or the quantities are relatively modest. The Rev Speidell at Crick was exceptional in owning 400 ounces of silver; more typical were his counterparts at Broughton (1790) and Orlingbury (1824), where there were just 17 and 16 pieces of silver being sold in total. ${ }^{32}$ Nor were these pieces engraved with arms and crests like those owned by titled aristocrats. In this, they had much in common with their gentry neighbours whose silverware was similarly unadorned.

Similar qualitative differences were apparent in their prints and paintings, and their scientific instruments. The latter appears in the homes of several clergymen including the Rev Reynolds at Little Bowden (1830), who was clearly interested in astronomy, yet his investment does not appear to have run beyond a telescope and stand. His contemporary, the Rev Durham of Burton Latimer (1833), had a solar microscope and an electrifying machine, both of which speak of a practical interest in science, but one that was fairly limited in scope

\footnotetext{
${ }^{29}$ NCL, Sale Catalogue for Rolleston Hall, 1801, M0005647NL/2, 10.

${ }^{30}$ NCL, Sale Catalogue for Cottingham, 1772, M0005644NL/2, 11; Sale Catalogue for Welton Place, 1830, M0005644NL/13, 17-18.

${ }^{31}$ NCL, Sale Catalogue for Crick rectory, 1836, M0005644NL/19, Crick, 1836, 11; Sale Catalogue for Weldon rectory, 1761, M0005646NL/1, Weldon, 1761, 7 .

${ }^{32}$ NCL, Sale Catalogue for Crick rectory, 1836, M0005644NL/19, Crick, 1836, cover; M0005646NL/10, Broughton, 1790, 11, 19; M0005645NL/6, Orlingbury, 1824, 12.
} 
and in its material manifestation. ${ }^{33}$ Such modest equipment parallels that seen in several gentry houses in the sample: the 1829 sale at Geddington, for example, included a 'handsome telescope', but no other scientific equipment, whilst the un-named owner of Wollaston Hall had a fairly impressive three telescopes, globe and pedometer. Yet even this pales in comparison with the extensive collections assembled by some wealthy landowners. Edward, Fifth Baron Leigh, spent $£ 27$ 7s on an air pump, syringes, receivers, cylinder glasses, funnels, hemispheres, and other equipment from Edward Nairne, a noted scientific instrument maker of Cornhill in London. ${ }^{34}$

It is possible, then, to see these prosperous clergymen as materially and socially aligned with the lesser gentry. This is especially apparent in their possession of an array of objects which allowed them to engage in the kind of polite and increasingly informal sociability which marked gentility. In de Vries's analysis this was 'new luxury': socially inclusive and linked to refined practices and performances of taste and sociability. ${ }^{35}$ This is best illustrated in the ownership of tasteful and comfortable furniture, the equipage for tea drinking and social dining, and the more general gathering together of such things in assemblages that marked rooms as spaces of refined sociability. Taking these in turn, many of the sale catalogues itemise an array of furniture, often en suite, which would create an informal and comfortable room. In his drawing room at Titchmarsh, (1788) the Rev Pye had a mahogany framed sofa covered with green morine; a set of twelve armed chairs, 'painted India bamboo pattern' with green morine seats, a Wilton carpet, and green morine curtains. There were two mahogany card tables, a mahogany Pembroke table, and three small fire screens. ${ }^{36}$ His family and guests could thus sit in comfort whilst playing cards, reading or talking - either together or in small groups. Similarly, the Rev Whalley at Ecton (1838) could accommodate his guests on a large sofa, a couch, an ottoman, four easy chairs and five chairs, each with chintz covers. The white and gold carved pier table, ormolu mounted chiffonier, and pair of 'fancy' tables added a touch of grandeur to the room, but there was also a work table, writing table, loo table,

\footnotetext{
${ }^{33}$ NCL, Sale Catalogue for Little Bowden rectory, 1830, M0005645NL/14, 12; Sale Catalogue for Burton Latimer rectory, 1833, M0005645NL/20, 8.

${ }^{34}$ Stratford Central Library and Archives, Receipted bill dated 6 November 1765, DR18/5/4385. See Stobart and Rothery Consumption and the Country House, p.122.

${ }^{35}$ De Vries, Industrious Revolution, pp.44-5.

${ }^{36}$ NCL, Sale Catalogue for Titchmarsh rectory, 1788, M0005646NL/8, 11.
} 
book stand, a small bookcase, a Canterbury, and what-not, and a set of occasional tables. ${ }^{37}$ These were the kind of pieces that DeJean calls 'convenience furniture' and would have made Whalley's drawing room both comfortable and convenient. ${ }^{38}$

Dining and tea drinking were rendered polite and genteel performances by the use of fashionable porcelain and silverware. The latter was rarely seen in the sales at clergy houses, but when it did appear silverware generally comprised cutlery, candlesticks, decanter stands and cruets, all of which would have added shine to the dining table. Porcelain was far more widely owned, generally being listed in terms of sets for dining, or for drinking tea, coffee and more occasionally chocolate. Fairly typical is the chinaware owned by the Rev Rose at Broughton. He had a dinner service comprising 42 plates, 18 desert plates, 12 soup plates, and an assortment of serving plates and dishes, including a covered soup tureen and a salad bowl. He also had a set comprising tea pot, 12 tea cups and saucers, 12 coffee cups and saucers, a sugar bowl and a water bowl, plus two smaller tea sets, several sets of cups and saucers, and numerous individual pieces. Of particular note is that five of his teapots were black. Kate Smith has noted how these were especially prized in showing off the delicate white hands of the hostess who would be pouring the tea and elegance of her movements in undertaking these duties. ${ }^{39}$ Their presence in the rectory at Broughton suggests that Pye and his wife were engaged in such genteel performances and were aware of the prevailing fashion in chinaware and polite entertaining. The rooms in which this porcelain would have been used were themselves embodiments of new luxury. The Rev Rose's Best Parlour contained a pair of dining tables, eight chairs, a cellaret, a tea chest and a tea caddy, all made from mahogany; there was also a tea caddy and a backgammon table. On the walls hung a series of prints, including a mezzotint of David Garrick in the character of Macbeth, two landscapes and a copy of a Van Dyke painting. Next door, in the Little Parlour, there were four chairs, a window seat and a pair of 'slope-sided easy chairs', together with a Pembroke table and two

\footnotetext{
${ }^{37}$ NCL, Sale Catalogue for Ecton rectory, 1838, M0005644NL/24, 20-21.

${ }^{38}$ Jean DeJean, The Age of Comfort (New York, 2009), pp.131-9

${ }^{39}$ K. Smith, 'In Her Hands: Materializing Distinction in Georgian Britain', Cultural and Social History, vol 11:4 (2014), pp.489-506.
} 
card tables. Together they formed almost copybook examples of the kind of domestic environment created for refined and polite entertaining. ${ }^{40}$

\section{Describing goods, declaring quality and defining culture}

The clergymen examined here had houses that spoke of more than respectability; the range of high status goods indicates alignment with ideals of gentility and, more specifically, with the material culture of their gentry neighbours. Yet many of these goods were also found in the homes of the urban middling sort. They too owned mahogany furniture, chintz curtains, Staffordshire porcelain, as well as books, silverware, clocks and the like. In this sense, there was often no hard divide between different sections of society in terms of the type of things that were found in their homes. The landowning classes might distinguish themselves through the size of their houses and their possession of old luxuries, which remained beyond the reach of most householders by virtue of their cost, the 'reach' needed to acquire them, and their semiotic complexity. ${ }^{41}$ More generally, however, distinctions might be made in terms of the quality of particular items. There was kudos in owning damask tablecloths, rosewood furniture, Dresden porcelain and copies of paintings by old masters. Quality can be elusive in inventories, but it is often apparent in the descriptions of goods in auction catalogues. Here, I examine three aspects of this: descriptions of the physical characteristics of individual pieces, indications of the provenance of objects, and the use of adjectives to describe the material or aesthetic qualities of a wide range of household goods. Together, these can offer invaluable insights into the domestic material culture of the clergy: the ways in which their possessions were framed by linguistic and cultural contexts. ${ }^{42}$

Auction catalogues reflect an imperative to sell, which no doubt encouraged auctioneers to talk up the quality and thus the value of the objects available. Some auctioneers reacted by eschewing florid descriptions, the sale catalogues for the rectories at Titchmarsh and Cranford St Andrew (1822), for example, included materials and sizes, but there is no attempt

\footnotetext{
${ }^{40}$ See Vickery, Behind Closed Doors, pp.129-65; M. Ponsonby, Stories from Home: English Domestic Interiors, 1750-1850 (Aldershot, 2007), pp.25-33.

${ }^{41}$ Berg, Luxury and Pleasure, pp.21-45. This links to Appadurai's register of luxury - see A. Appadurai, 'Commodities and the politics of value', in A. Appadurai (ed.) The Social Life of Things: Commodities in Cultural perspective (Cambridge, 1986).

${ }^{42}$ Smith, Consumption and the Making of Respectability, pp.5-24.
} 
to enthuse the potential buyer through eloquent pen portraits of the goods on offer. ${ }^{43}$ Thus we see in the dining parlour at Titchmarsh a 'mahogany dining-table, 3 feet 8 inches', a 'chimney glass, painted frame, middle plate 27 by 15 , end plates 15 by 14', and a 'pair of blue spun silk festoon window-curtains'. ${ }^{44}$ Taking this a stage further, the auctioneer organising the 1787 sale at Islip Mills, declared in the catalogue that 'Bombast Puffing of Pictures, as well as of other Articles, is always ridiculous; as not furnishing any just or clear Ideas by which the unskilled may form any judgment of their Merits, but at the same time never fails to excite the Laughter and Contempt of the Connisseur [sic.]'. ${ }^{45}$ Few followed this lead and auctioneers frequently offered lenghty and persuasive descriptions. The listing for the cabinet at Rolleston Hall, noted earlier, was particularly lengthy, but two or three lines were frequently accorded to items including curtains, sofas, dressing tables and mirrors, detailing their size, materials, colour and finish. ${ }^{46}$

Sale catalogues for parsonages rarely reached quite the same rhetorical heights, but many offered detailed and sometimes rather florid descriptions. This was especially true for the larger and more grandly furnished rectories where sales continued for several days. This was certainly true at Broughton (6 days), Ecton (5 days) and especially Crick (6 days) where we see countless items described in ways that closely mirror the entries in gentry sale catalogues. In room 7 at Crick, a bed chamber, we have a 'superior Spanish mahogany double washhandstand, with rising top, dressing glass, 2 drawers, and kneehole, on turned legs and castors', and in the drawing room, we find 'two pair of elegant blue merino damask window curtains, trimmed with silk gymp, deep fringed valens, holders and tassels, carved imitative oak cornices, laths and rods'. ${ }^{47}$ Even at small sales, such as that of the possessions of the Rev Henry Hoare in 1809, the auctioneer could wax lyrical, the best bed room containing a 'handsome mahogany fluted pillar'd lath bottom bedstead ( 5 feet 9 wide) white striped dimity furniture, elegant drapery, rich chints border, japan cornice, festoon window-curtain to

\footnotetext{
${ }^{43}$ NCL, Sale Catalogue for Titchmarsh rectory, 1788, M0005646NL/8; Sale Catalogue for Cranford St Andrew rectory, 1822, M0005645NL/3.

${ }^{44}$ NCL, Sale Catalogue for Titchmarsh rectory, 1788, M0005646NL/8, 4.

${ }^{45}$ NCL, Sale Catalogue for Islip Mills, 1787, M0005645NL/5.

${ }^{46} \mathrm{~J}$. Stobart, 'The language of luxury goods: consumption and the English country house, c.1760-1830', Virtus, 18 (2011), pp.95-6.

${ }^{47}$ NCL, Sale Catalogue for Crick rectory, 1830, M0005644NL/19, 7 \& 15.
} 
correspond (by Siddons) '. ${ }^{48}$ Not only do such descriptions suggest a more active attempt to sell the goods on the part of the auctioneer, they also provide a vivid image of the material qualities of these clergymen's belongings. These were well-furnished houses, on a par with their gentry neighbours in both the quantity and quality of their furnishings.

As is apparent from the description of the washstand at Crick, provenance was sometimes an important point of reference. It tells us something of the material qualities of the object and also indicates its economic or cultural value. Here again, we can see the clergy houses occupying a similar world to those of the gentry, but perhaps lacking the kudos afforded by the presence of metropolitan and European luxury goods. The catalogue for the 1823 sale at Geddington House, for instance, made much of the fact that the furniture was 'principally supplied by Messrs. GILLOWS, within these Three Years', and the lots included a variety of decorative French porcelain. ${ }^{49}$ Nonetheless, the maker's names were included against a wide variety of items, no doubt to underline the quality and desirability of the items being sold. Most frequently named was Wedgwood porcelain, the cachet of the maker sometimes being underlined by the fashionability of the design, as at the rectory in Broughton where a 'Tableset of the neat much improved Staffordshire Ware with the greatly admired Blue-tinged Edges, which gives it all the genteel Effect of a Service of China'. ${ }^{50}$ The phrasing here is revealing: in telling potential buyers that Staffordshire ware is 'much improved' and the particular design is 'greatly admired', the auctioneer was offering reassurance about the material and visual qualities of the porcelain as well as its symbolic value as tasteful tableware. The goods are thus simultaneously situated in commercial, aesthetic and cultural contexts that aligned them with gentility. Worcester and Dresden porcelain were also itemised at Crick and elsewhere, indicating that there was some discernment being shown about which manufacturer might produce the most desirable items for particular use. The makers were again identified for many of the musical and scientific instruments being offered for sale: a Collard piano at Crick, a flute by Clementi and a piano by Goulding, D'Alamain \& Co. at Corby; a Borrowman piano and Newton globes at Cranford St Andrew. ${ }^{51}$ To some

\footnotetext{
${ }^{48}$ NCL, Sale Catalogue for Knuston Hall, 1809, M0005647NL/9, 12.

${ }^{49}$ NCL, Sale Catalogue for Geddington House, 1823, M0005644NL/8, 1, 15, 16.

${ }^{50}$ NCL, Sale Catalogue for Broughton rectory, 1790, M0005646NL/10, 10.

${ }^{51}$ NCL, Sale Catalogue for Crick rectory, 1830, M0005644NL/19, 16; Sale Catalogue for Corby rectory, 1842 , M0005645NL/23, 8-9; Sale Catalogue for Cranford St Andrew rectory, 1822, M0005645NL/3, 12.
} 
extent, all of these might be seen as branded goods: a known and trusted name acting as a symbol and guarantor of the quality of the piece. As such, it links the clergy into a more modern world of brands and mass consumerism that might be viewed as being at odds with attempts to distinguish themselves through their material culture. In reality, and with the possible exception of the Staffordshire ware of Wedgwood and others, these were far from being goods aimed at a mass market. A piano from Borrowman of Soho, for example, said much about the reach and knowledge of the consumer because such items were not available locally in Northamptonshire - except, of course, from sales such as these.

Provenance could also be signalled in a more general sense, most frequently through identifying goods by their country of origin, although these should not always be taken at face value. For example, the Rev. Pye at Titchmarsh owned a diverse range of porcelain, including a 'breakfast set of blue and white Nankeen', a 'fine large India punch-bowl', and a 'complete long set of burnt-in fine India tea-china'. Whether this was genuine Chinese porcelain is impossible to tell, but the label remains significant in that it signalled an association with the orient that was tangible as much as cultural. ${ }^{52}$ Much the same is true of the 'Five raised Figures of India Birds, in four Japan Frames, viz. Chinese Painted Cock Pheasant,- Long-tailed Parrket - Purple and white Chinese Cock and Hen Phesant - and Blue, Red and Yellow Maccaw' found in the closet adjoining the Best Chamber in the rectory at Broughton. ${ }^{53}$ Both the character and likely provenance of the goods linked these rural rectories to a wider world of empire and commerce, but also of cultural cosmopolitanism and exoticism. ${ }^{54}$ Such associations are most strikingly illustrated in a single object: the 'handsome tiger skin' found in the Rev Whalley's drawing room in Ecton. There is no way of knowing how this came to rural Northamptonshire, but even if it was acquired via a London dealer or from another house sale, it speaks of an imaginative connection to the orient and an immersion in a growing taste for the exotic. This was seen throughout Whalley's house: the kingwood and rosewood furniture in his drawing room, the Turk's head on the stairs or the

\footnotetext{
${ }^{52}$ NCL, Sale Catalogue for Titchmarsh rectory, 1788, M0005646NL/8, 6.

${ }^{53}$ NCL, Sale Catalogue for Broughton rectory, 1790, M0005646NL/10, Broughton, 1790, 9.

${ }^{54}$ See, inter alia, Berg, Luxury and Pleasure, pp.46-84; T. Nechtman, Nabobs: Empire and Identity in Eighteenth-Century Britain (Cambridge, 2010); J. Eacott, Selling Empire: India in the Making of Britain and America, 1600-1830 (Chapel Hill, 2016); M. Finn and K. Smith (eds), The East India Company at Home, $1757-$ 1857 (London, 2018).
} 
inlaid Indian chest and two 'beautifully carved ivory candlesticks' in a bedroom. ${ }^{55}$ Like his landowning neighbours, Whalley was deeply immersed in the material culture of empire in terms of the provenance of materials and specific objects, and a more general aesthetic. Again like many country houses, these things were spread throughout the rectory at Ecton making it difficult to determine the precise meaning and impact of these objects. ${ }^{56}$ The catalogues alone do not tell us if this clergyman was subscribing to the imperial project through his material culture or if he had a particular taste for the exotic, or if he was less selfaware and simply following the dictates of fashion.

As the descriptions of Whalley's tiger skin and ivory candlesticks indicate, the quality of items was also communicated through the use of adjectives. These tied goods into wider systems of aesthetics, taste and cultural norms and were deployed both on the covers and alongside individual items. ${ }^{57}$ Unlike the sales of goods from gentry houses, auctioneers made no claim that the goods sold from clergy houses were 'genuine', presumably because it was felt that there was no need to assert their authenticity in this way. In this context, 'genuine' connects goods to the householder and acts as an indicator of social capital: the potential buyer is reassured about the quality of the goods on offer (they are not detritus from previous sales) and is simultaneously linked to the previous owner. ${ }^{58}$ The latter would matter more if the goods being sold once belonged to the earl of Halifax or came from Kirby Hall; it became less important in the case of vicars and parsonages. The most common descriptions on the covers of catalogues for clergy sales fall into three groups. First, there were assertions that the things being offered for sale were 'valuable' and 'modern', together seen in nearly half of the catalogues. The former is a reminder that used goods retained economic value and that second-hand was by no means the resort of the poor. The latter indicates the cultural currency of the objects; if not exactly fashionable, they are at least up to date and would thus form suitable adornments in respectable or even genteel houses. Second was the claim that these

\footnotetext{
${ }^{55}$ NCL, Sale Catalogue for Ecton rectory, 1840, M0005644NL/24, 20-21 \& 25.

${ }^{56}$ On the impact of empire on the aesthetic and meaning of country houses, see S. Barczewski, Country Houses and the British Empire, 1700-1930 (Manchester, 2014); S. Sloboda, Chinoiserie: Commerce and Critical Ornament in Eighteenth-Century Britain (Manchester, 2014); Finn and Smith, East India Company at Home.

${ }^{57}$ Stobart, 'Language of luxury'.

${ }^{58}$ C. Wall, The Prose of Things: Transformations of Descriptions in the Eighteenth Century (Chicago, 2006); Stobart, 'Luxury and country house sales'.
} 
things were 'useful', a quality that might most obviously link to kitchenware and husbandry ware (important elements of many sales, but beyond the scope of this paper), but also a reminder of Maxine Berg's argument that many the items becoming available to householders through the eighteenth century were attractive because of their utility as well as their novelty. ${ }^{59}$ It is significant, therefore, that useful was always deployed in conjunction with genteel: these goods would bring practical and symbolic benefits to their new owners. This takes us to the third set of labels, those which carried aesthetic and social meanings. For Vickery, genteel and elegant 'embodied the social distinctions of provincial gentility' and helped to tie these goods and the clergymen who had owned them to the sphere of their gentry neighbours. ${ }^{60}$

Opening up the catalogues, the language changes. As with the gentry catalogues, usefulness and value disappear and the goods are described either in terms of their declared quality (excellent, capital) or aesthetic qualities (handsome, elegant, neat). ${ }^{61}$ However, the use of descriptive language in catalogues for clergy sales is both less widespread and less diverse than in gentry catalogues (Table 2). Of the 14 catalogues that included some qualitative descriptions, five deployed excellent, mostly to describe furniture. This ranged from to the 'most excellent 8-day dial clock' sold from the rectory at Rushton to the 'excellent Spanish mahogany-framed dressing glass' at Ecton. ${ }^{62}$ Its precise meaning is difficult to discern, but it certainly communicated the superior quality of the piece in terms of workmanship, design and materials. This becomes more apparent in a phrase used for several items in the sale at Corby (1842) where the dining room contained a 'very excellent town-made set of mahogany dining tables' and a 'very excellent town-made mahogany sideboard'. These contrasted with the following item - a 'mahogany cheffonier [sic] with drawers' - in a way that emphasises the superior quality of the first two items, where their excellence is layered onto their

\footnotetext{
${ }^{59}$ M. Berg 'New commodities, luxuries and their consumers in eighteenth-century England' in M. Berg and H. Clifford (eds.) Consumers and Luxury (Manchester, 1999), pp. 63-85

${ }^{60}$ A. Vickery, The Gentleman's Daughter. Women's Lives in Georgian England, (New Haven, 1998), p.161.

${ }^{61}$ Stobart, 'Language of luxury', pp.97-8. This draws on ideas of speech-act theory. See J. Searle, Speech Acts. An Essay in the Philosophy of Language (Cambridge, 1969); J. Searle, 'A taxonomy of illocutionary acts', in K. Günderson (ed.), Language, Mind, and Knowledge (Minneapolis, 1975).

${ }^{62}$ NCL, Sale Catalogue for Rushton rectory, 1809, M0005647NL/9, 14; Sale Catalogue for Ecton rectory, 1842 , M0005644NL/24, 25.
} 
metropolitan provenance, the one reinforcing the other. ${ }^{63}$ Much could be said of the superlative 'capital', which was also used in conjunction with town-made to underline the quality of the piece - effectively declaring it as the best quality. ${ }^{64}$ This term was deployed for a wider range of goods, including firearms. There was a 'capital fowling piece, silver mounted' in the rectory at Braybrooke (1828) and another 'capital fowling piece, with roller lock and gold touch hole by Steele' at Lowick rectory (1816). ${ }^{65}$ In both cases, the gun was identified as being of superior quality in terms of materials and manufacture. Applied to furniture, it appears to have signified particularly large or impressive pieces: the 'set of capital solid Spanish mahogany dining tables on extending frames and massive reeded legs, with brass castors, $5 \mathrm{ft}$ wide and $14 \mathrm{ft} 7$ long' sold at Crick. ${ }^{66}$

Table 2. Adjectival descriptors of goods listed in catalogues for gentry and clergy house sales in Northamptonshire, 1761-1842

\begin{tabular}{lcccc}
\hline & \multicolumn{2}{c}{ Gentry $(\mathrm{n}=24)$} & \multicolumn{2}{c}{ Clergy $(\mathrm{n}=21)$} \\
& Number & Percentage & Number & Percentage \\
\hline Fine & 14 & 58 & 1 & 5 \\
Excellent & 11 & 45 & 5 & 24 \\
Capital & 8 & 33 & 6 & 29 \\
Superior & 1 & 4 & 2 & 10 \\
Handsome & 16 & 67 & 11 & 52 \\
Elegant & 11 & 45 & 5 & 24 \\
Neat & 8 & 33 & 8 & 38 \\
Beautiful & 9 & 38 & 1 & 5 \\
Genteel & 2 & 8 & 0 & 0 \\
Curious & 3 & 13 & 0 & 0 \\
Valuable & 2 & 8 & 0 & 0 \\
\hline
\end{tabular}

Source: Volumes of auction catalogues, Northamptonshire Central library, M0005644-7NL

\footnotetext{
${ }^{63}$ NCL, Sale Catalogue for Corby rectory, 1842, M0005645NL/23, Corby, 1842, 7.

${ }^{64}$ See C. Richardson, A New Dictionary of the English Language (London, 1839).

${ }^{65}$ NCL, Sale Catalogue for Braybrooke rectory, 1828, M0005645NL/11, 4; Sale Catalogue for Lowick rectory, 1816, M0005647NL/16, 5.

${ }^{66}$ NCL, Sale Catalogue for Crick rectory, 1830, M0005644NL/19, 10.
} 
From such descriptions, it is clear that a number of rectories contained impressive, well-made and high quality furnishings. However, it was aesthetic descriptions that were most frequently deployed, indeed, all the catalogues that included qualitative descriptions used at least one of these terms (Table 2). Almost anything could be handsome, from the 'two pair of handsome brass candlesticks' at Grafton Underwood, (1794) and the 'handsome chintz French window curtain, lined and fringed' at Rothwell (1816), to the 'set of handsome mahogany telescope dining tables, with circular ends' at East Farndon (1838). ${ }^{67}$ As with capital, this indicated to late eighteenth-century lexicographers like James Barclay ideas of grandeur or dignity, and a sense of beauty and grace. ${ }^{68}$ Two generations later, it was being layered with additional meanings, Charles Richardson defining it 'cleverly or skilfully done; and thus, further, suitable or well adapted' - a very fitting description for well-made furniture. ${ }^{69}$

At both gentry and clergy sales, 'elegant' was used to describe a variety of furniture, mirrors and chinaware. Contemporary definitions linked it specifically with gentility, refining the idea of status with that of beauty. As Barclay put it: 'genteel implies something above the common run; elegant means beautiful without grandeur'. Remarkably, his definition focused specially on furniture: 'By a house genteelly furnished is understood a house containing every necessary, good and creditable; by elegantly furnished is meant genteelly, and in such a manner as to please without elevation'. Elegance was thus a refinement of taste and beauty, to which Richardson added notions of discernment and the sense of something 'highly wrought, highly polished' ${ }^{70}$ These complex meanings are well illustrated in the drawing room at Crick. The rosewood what-not, Canterbury and chess table were all 'handsome'; the rosewood Davenport writing desk was 'capital'; the case for the piano was 'superb', and the plate chimney glass was 'noble' and 'brilliant'. Alongside these were a 'very elegant 6 - $\mathrm{ft}$ carved rosewood Grecian chaise longue', 'a very elegant 5-ft winged rosewood commode, with carved pilasters', 'a pair of elegant flower-pattern and gold china candlesticks', and 'a

\footnotetext{
${ }^{67}$ NCL, Sale Catalogue for Graton Underwood rectory, 1794, M0005646NL/12, 5; Sale Catalogue for Rothwell rectory, 1816, M0005647NL/17, 4; Sale Catalogue for East Farndon rectory, 1838, M0005644NL/22, 17.

${ }^{68}$ See J. Barclay, A Complete and Universal English Dictionary (London, 1799).

${ }^{69}$ Richardson, New Dictionary.

${ }^{70}$ Barclay, Complete and Universal English Dictionary; Richardson, New Dictionary.
} 
pair of very elegantly carved rosewood pole fire-screens'. ${ }^{71}$ These pieces were elegant in the sense of beauty without grandeur, and in their workmanship and finish; both furniture and description linked the parsonage with gentility.

Notably absent from the list of adjectives used by the auctioneers at Crick was the word 'neat', although they deployed it elsewhere in the house. It carried connotations of elegance and skill, but 'void either of splendour or dignity' as Barclay put it. For Amanda Vickery, it conveyed restrained good taste and, as she observes, was often used to describe wallpapers. ${ }^{72}$ As with gentry sales, its application in the clergy sale catalogues appears to connote similar meanings of modest good taste. At the rectory in Braybrooke, the drawing room contained a 'neat mahogany sofa' and a 'neat mahogany bookcase with glazed folding door \& secretaire'. These were set alongside suite of 'handsome' Grecian couch, chairs and card tables and the 'handsome chimney glass'. ${ }^{73}$ The relatively modesty of pieces described as neat is still more apparent when we step outside at Braybrooke. In the coach-house, there was a 'handsome close carriage, in complete repair, with imperial and front $\&$ back seats' and also a 'neat single horse chaise (nearly new) \& neat set of harness'. The larger, more imposing carriage is handsome; the smaller, lighter chaise is neat.

Handsome, elegant and neat all linked into notions of refined and polite taste, thus tying these second-hand goods and their clergy owners into wider value systems. It is significant that they played on notions of gentility, and on correctness and restraint, rather than emphasising the opulence and intrinsic luxury of the pieces. Only on rare occasions did adjectives obviously link to either the sensuous nature of luxury or ideas of splendour: 'rich' and 'splendid' are very sparingly used, appearing in only three gentry and two clergy catalogues, and nowhere do we see luxury or luxurious. Even with highly ornate and richly decorated pieces, the language remains restrained. At Crick, for example, a gilt china and ormolu lamp with an engraved glass shade was described as 'very elegant'. ${ }^{74}$ The clergy were thus closely aligned with their gentry neighbours through the descriptions chosen by auctioneers who

\footnotetext{
${ }^{71}$ NCL, Sale Catalogue for Crick rectory, 1830, M0005644NL/19, 16-17.

${ }^{72}$ Barclay, Complete and Universal English Dictionary; Vickery, Behind Closed Doors, pp.180-182.

${ }^{73}$ NCL, Sale Catalogue for Braybrooke rectory, 1828, M0005645NL/11, 4-5.

${ }^{74}$ NCL, Sale Catalogue for Crick rectory, 1830, M0005644NL/19, 16.
} 
clearly saw parsonages, manor houses and even country houses occupying the same material world; one described and defined by the language of gentility.

\section{Conclusion}

In presenting this analysis of the household goods of the rural clergy I do not pretend that all clergymen were the same. Some livings were far more valuable than others; combining them, a far from uncommon practice, could provide an income of several hundred pounds per annum and elevate the social standing of the incumbent. At the opposite end of the scale and outside the bounds of this paper - were the curates, often employed by wealthy rectors and vicars to carry out some or all of their duties. It is scarcely surprising, then, that some of the houses studied here were grander and more handsomely furnished than were others. The rectories at Broughton, Orlingbury, Ecton and especially Crick were particularly large and the length of the auctions indicates the richness of their material culture - easily on a par with the houses of neighbouring gentry. That said, all of the rectors and vicars included in this study shared the same social world: one marked by gentility rather than mere respectability. Of itself, this is perhaps unsurprising, but the extent to which these men and their families enjoyed the material trimmings of gentility is remarkable: from the neat chaise in the coach house, to the elegant ormolu candlestick, to the handsome exoticism of a rosewood loo table. Significantly, this material world was more closely linked to notions of taste and inclusive sociability than to ostentatious displays of status through exclusive luxury objects. To be sure, these clergymen's drawing rooms and dining rooms were tastefully and richly furnished, but they were also comfortable and welcoming spaces where the furnishings allowed for informal sociability. In this, they were part of a more general shift in domestic culture and material culture, though whether we view it as new luxury, the rise of the informal house or the triumph of comfort is a matter of perspective. But gentility was not simply a product of the material objects themselves; it was also produced through the language deployed in the sale catalogues. Here we see the auctioneers who drew up these catalogues linking the clergymen's possessions to notions of refined taste and gentility through the ways in which they described the goods being sold. The chaise was neat, the ormolu candlestick was elegant and the loo table handsome.

Turning the argument around, what do these clergy houses tell us about gentility and about the ways in which material possessions were perceived and valued? Most obvious is the 
observation that gentility was, at least in part, materially defined. Possessing the domestic trappings of gentility did not necessary make these vicars and rectors gentlemen, but it did help to incorporate them into the same social, cultural and material world. It is important to note, however, that ownership was but the first step: gentility required assemblages of objects to create an active setting for refined social practices and their appropriate use in the changing rituals of polite sociability. In this, material possessions were not necessarily valued and valorised in terms of the novelty or fashionability, as much of the consumption literature would lead us to believe. Rather, it was the language of quality, workmanship and aesthetics that dominated. Whether we take auctioneers' descriptions at face value or as a sales pitch, they were clearly using language in a way that was attuned with their potential customers. Overall, then, gentility was defined and communicated through domestic goods, social practices and language - a web of interactions revealed vividly in the pages of auction catalogues. 